\title{
Het verborgen verleden
}

'In Spanje zijn de doden levender dan de doden waar ook ter wereld: hun aanwezigheid verwondt als een scherpgeslepen scheermes', zo schreef de Spaanse dichter Federico García Lorca. ${ }^{1}$ Hij kon niet vermoeden dat zijn doden meer dan zeventig jaar later nog zo scherp door het huidige Spanje zouden snijden.

Lorca is zelf een van de beroemdste slachtoffers van de Francoterreur: hij werd in het begin van de Spaanse Burgeroorlog vermoord door nationalistische soldaten. Zoals

zovele duizenden slachtoffers van Franco's represailles tegen de rojos ('de rooien'), ligt hij nog steeds ergens anoniem onder de aarde.

Spanje leefde veertig jaar onder een dictatuur. Die eindigde niet zoals in Portugal door een - weliswaar bijna geweldloze - revolutie, maar door het overlijden van haar

dictator. In tegenstelling tot de Argentijnse dictatuur of het apartheidsregime in Zuid-

Afrika, werd geen enkele onder de dictatuur begane misdaad sindsdien onderzocht of veroordeeld. Over de 'republikeinse' doden werd gezwegen, de slachtoffers aan nationalistische kant werden in gewijde grond herbegraven en in ere hersteld. Pas sinds het einde van de jaren 1990 klinken de stemmen uit het verleden weer op en wordt het taboe doorbroken. En opent zich een doos van Pandora ...

Over die doorbraak van de republikeinse herinnering, de zoektocht naar de waarheid en hoe die het huidige Spanje, tot zelfs zijn historici, verdeelt, vertelt David Huys in een eerste bijdrage.

Een tweede bijdrage is van de hand van Ger Harmsen. Naast sociaal-historicus was Harmsen een enorm natuurliefhebber. Hij schreef het boek Natuurbeleving en arbeidersbeweging, waarin hij inging op de verhouding tussen links en de natuur. In zijn natuurbeleving voelde hij een grote verwantschap met Jean-Jacques Rousseau, met wie hij zich sterk identificeerde. Toen hij overleed, was hij nog volop bezig aan een artikel over Rousseau en diens passie voor mossen. Samen met enkele historici, familieleden en veldbiologen, maakte prof. dr. Bob Reinalda dit artikel klaar voor publicatie in Brood \& Rozen.
In de rubriek Opgemerkt vertrekt Marc Constandt vanuit zijn eigen privécollectie op een verkennende ronde naar de historiek van de Belgische reisbureaus. Aanvankelijk waren die een privilege voor de gegoede burgerij, maar sinds de doorbraak van het massatoerisme zijn ze lang geen luxeproduct meer.

Joris van Parys, biograaf van Frans Masereel, vertelt in zijn bijdrage over de - zeer late doorbraak van de auteur in Frankrijk.

Martijn Vandenbroucke presenteert in de rubriek Collectie het vervolg van de Belgische archieven in Moskou en Jessica Langouche heeft een nieuw 'groen' en duurzaam archief verwerkt, dat van Ecolife. En om nog even in de sfeer van de verkiezingen te blijven, tonen we enkele verkiezingsgadgets uit onze collectie, van toen die nog niet verboden waren.

In de rubriek Kroniek brengt Piet Creve verslag uit van de zeer interessante workshop rond het project Stafkaart van het migrantenmiddenveld en zijn erfgoed in Vlaanderen 1830-1990, die eind februari door KADOC-K.U.Leuven en Amsab-ISG werd georganiseerd.

Volgen nog enkele voorstellingen en recensies van publicaties die, met enkele uitzonderingen, zelden de weg vinden naar het grote publiek, maar daarom niet minder lezenswaard zijn.

Brood \& Rozen, verrassend, afwisselend en beklijvend. Een boekje dat meemoet in je vakantiebagage.

Paule Verbruggen

Zie: Giles TREMLETT, Spaanse spoken. Reizen door het verborgen verleden van een land, Amsterdam/ Antwerpen: Atlas, $511 \mathrm{p}$ 


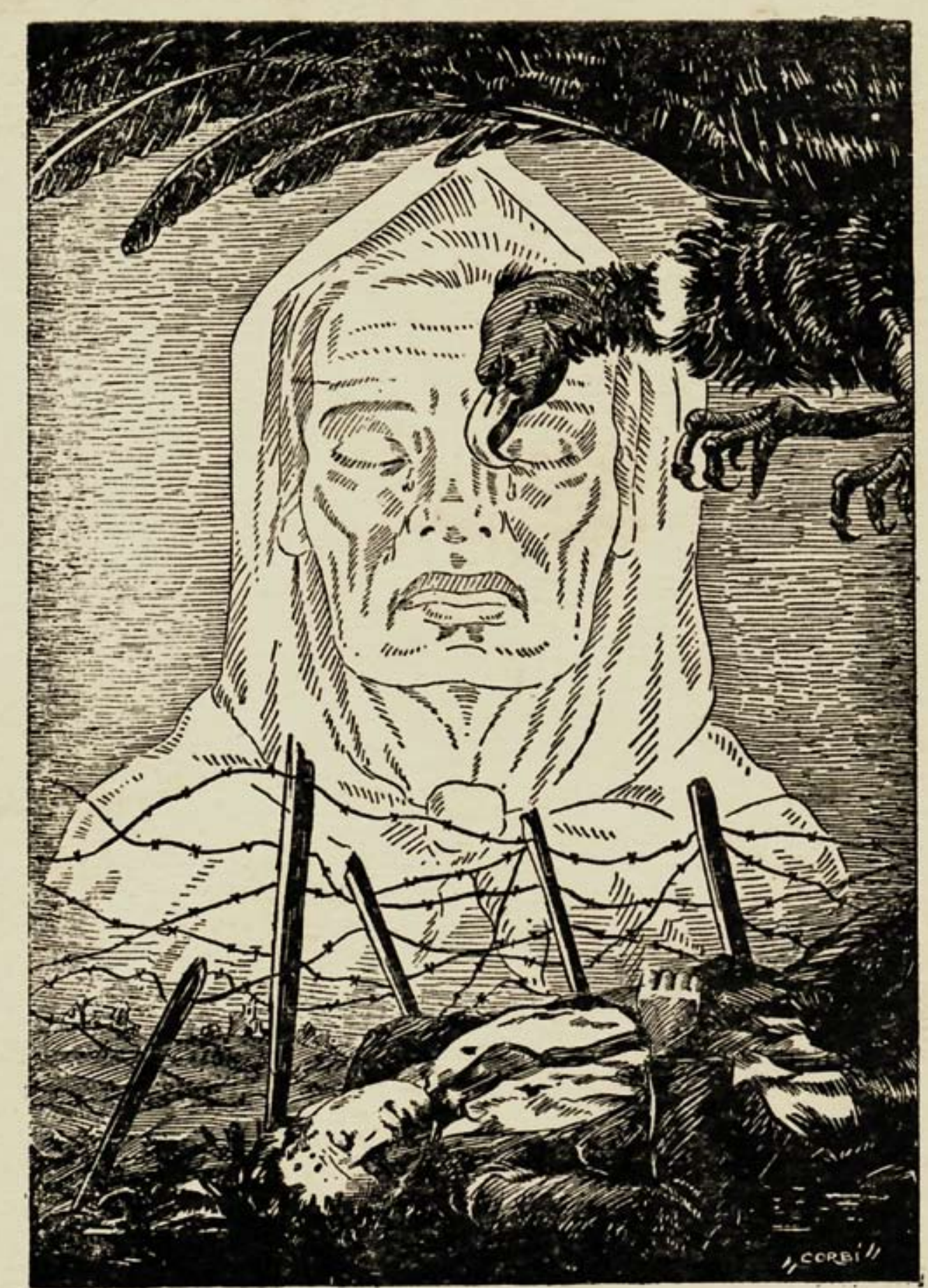

PRIMER AN̄O TRIUNFAL. FRANCO! FRANCO!! FRANCO!!!

Première onnée triomphale. Franco! Franco!! Franco!!! First year of triumph. Franco! Franco!! Franco!!!
Stemmen uit het verleden.

De doorbraak van de republikeinse herinnering in Spanje

\begin{abstract}
Dit artikel gaat in op de bewustwording van een verborgen verleden in het midden van de jaren 1990 dat gerelateerd is aan de burgeroorlog en dictatuur in Spanje. Aan de hand van recente literatuur onderzoeken we welke factoren hieraan ten grondslag lagen, welke reacties die uitlokten en wat de invloed ervan is op de Spaanse samenleving. Het blijkt namelijk dat het ontstane debat een tweedeling teweeg heeft gebracht en dat er van een mogelijke consensus over dit verleden op korte termijn nog geen sprake is.
\end{abstract}

In Spanje leidt de herinnering aan de burgeroorlog (1936-1939) en de daaropvolgende dictatuur van Franco (tot 1975) tot felle discussies, in die mate zelfs dat je van 'twee Spanjes' kan spreken. Grofweg wordt het oorlogs- en dictatoriale verleden aan de ene kant beschouwd als een afgesloten periode, terwijl men aan de andere kant juist op zoek is naar disclosure.

In het midden van de jaren 1970 was er officieel gezien nog geen sprake van een verschillende kijk op het oorlogsverleden. Toen Franco in 1975 stierf, moest te allen prijze een nieuwe confrontatie tussen de twee Spanjes voorkomen worden. Openlijk terugkijken op deze zwarte bladzijde uit de Spaanse geschiedenis was taboe: de invoering van de democratie had er juist voor gezorgd dat Spanje zich officiee verzoend had met het verleden. De blik werd gericht op de toekomst, op de aansluiting met Europa, in plaats van 'lijken uit de kast te halen'. Voor mogelijke onverwerkte trauma's van de burgeroorlog was er in de jonge democratie geen plaats. Ook gedurende het overgrote deel van de regeerperiode van de socialistische Partido Socialista Obrero Español (PSOE, 1982-1996), werd het thema van de burger-

'Het eerste jaar van triomf'. Briefkaart van Corbi met een aanklacht tegen de Spaanse Burgeroorlog (Amsab-ISG, Gent) 
oorlog angstvallig vermeden. Pas in het midden van de jaren 1990 begon deze kijk op het verleden langzaam te veranderen. In de jaren die volgden, ontstond er een beweging die de burgeroorlog en de dictatuur opnieuw in het collectieve bewustzijn bracht. Dit artikel probeert op beknopte wijze weer te geven hoe dit proces precies verliep, welke gevolgen dit had en wat de huidige ontwikkelingen zijn.

\section{Een afgesloten hoofdstuk}

Op 15 oktober 1977 verscheen er in de Spaanse krant El País een reactie op de zojuis overeengekomen amnestie met betrekking tot alle politiek gekleurde misdaden van vóór 15 december 1976. Volgens de redactie moest het verleden vanaf dan alleen maar aangewend worden om te reflecteren over de oorzaken van de burgeroorlog en zodoende een herhaling te voorkomen. ${ }^{1}$ Deze reactie van de jonge, progressieve krant was het hoogtepunt van de zogenaamde verzoeningsherinnering die vanaf de jaren 1960 in Spanje domineerde. De algemene opvatting was dat met de goedkeuring van de amnestiewet de burgeroorlog een afgesloten hoofdstuk was in de Spaanse geschiedenis.

Hoe diep de verzoeningsgedachte verankerd zat in de Spaanse samenleving bleek uit de lange adem ervan: het zou tot diep in de jaren 1990 duren voordat men hier vraagtekens bij zette. Tot dan was de maatschappelijke functie van de herinnering aan de burgeroorlog er een van waakzaamheid. In 1996, tijdens de zestigste gedenkdag van het begin van de burgeroorlog, stelde schrijver en journalist Javier Pradera dat de herinnering aan de gepleegde wreedheden in de burgeroorlog ervoor gezorgd had dat de overgang dictatuur-democratie vreedzaam was verlopen. ${ }^{2}$ In haar pioniersonderzoek uit datzelfde jaar bevestigde ook Paloma Aguilar dit beeld. ${ }^{3}$ De traumatische herinnering aan de burgeroorlog in het midden van de jaren 1970 zorgde ervoor dat het conflict werd bestempeld als 'collectieve waanzin' waaraan iedereen schuldig was geweest. Net zoals Pradera, stelde Aguilar dat er zich alleen op dergelijke wijze een algemene consensus had kunnen ontwikkelen die de basis had gevormd van een succesvolle invoering van de democratie. Het laatste wat men wilde, was elkaar opnieuw in de haren vliegen en juist om die reden moest het verleden niet gebruikt worden als wapen tegen politieke opponenten. Op die manie kon de vreedzame overgang van dictatuur naar democratie bewerkstelligd worden Deze gedachte moest koste wat het kost vastgehouden worden, want het gevaar van een mogelijk nieuwe militaire staatsgreep lag, zeker tot Spanjes toetreding tot de NAVO in 1982, steeds op de loer. ${ }^{5}$ Men besloot daarom het verleden 'willekeurig te vergeten', om de toekomst van de jonge Spaanse democratie veilig te stellen. ${ }^{6}$

Hoewel de burgeroorlog als politiek en maatschappelijk debat hierdoor taboe werd verklaard, wilde dat niet zeggen dat dit ook het geval was voor het historiografische debat, integendeel zelfs: na de dood van Franco zijn er boekenkasten volgeschreven over het conflict tussen de twee Spanjes. Uit werk van historici als Santos Juliá, Julio Aróstegui en Francisco Espinosa blijkt bijvoorbeeld dat de beeldvorming omtrent de burgeroorlog vanaf 1939 tot nu, verre van een statisch proces is geweest. Voor Juliá wordt herinnering voortdurend onderworpen aan verandering, waardoor de kijk van de grootouders, ouders en kleinkinderen op het verleden wezenlijk van elkaar verschilt.? Aróstegui spreekt van achtereenvolgens de identificatie- of confrontatieherinnering (einde burgeroorlog tot begin jaren 1960), de verzoeningsherinnering (jaren 1960 tot midden jaren 1990) en de herstelherinnering (midden jaren 1990 tot heden). ${ }^{8}$ Espinosa ten slotte, gebruikt een iets andere invalshoek, namelijk die van de herinnering aan de franquistische repressie. Gedurende de periode 1936-1977 was er volgens hem sprake van een ontkenning van de herinnering, waarna tijdens de eerste etappe van het democratiseringsproces (tot 1981) het recente verleden op politiek niveau vergeten werd. Daarna was er het uitstel van de herinnering (1982-1996) en het herstel ervan (1996-2002). ${ }^{9}$

Dat er sprake zou zijn van een zwijgpact, een pacto de silencio, omtrent de herinnering wordt door Juliá afgewezen. Sterker nog, in 1996 concludeerde hij dat er binnen de Spaanse samenleving een verzadiging was van de herinnering aan de burgeroorlog..$^{10}$ De stelling dat de Spaanse samenleving de omvang van de gepleegde misdaden en de onderdrukking nooit heeft willen inzien, was verkeerd, aldus Juliá. ${ }^{11}$ Reeds tegen het einde van de jaren 1970 werd er over de burgeroorlog uitvoerig geschreven in de Spaanse geschiedenistijdschriften en ook de uitgeverswereld schroomde niet om het thema aan te snijden. ${ }^{12}$ Door de enorme verkiezingsoverwinning van de socialisten (PSOE) in $1982^{13}$ en de daarmee gepaard gaande nederlaag van de franquistische Alianza Popular - met als lijsttrekker Manuel Fraga, onder meer minister van Toerisme onder Franco - kon de trend dat de burgeroorlog en dictatuur definitief als een afgesloten hoofdstuk uit de geschiedenis werd gezien, zich voortzetten. Met die overwinning was het franquisme definitie verslagen. De algemene opvatting binnen de regeringspartij PSOE was dat men he verleden maar best met rust kon laten en hieromtrent beter geen enkel beleid ontwikkelde. Het bijeffect was dat de sporen van het verleden zoals bijvoorbeeld franquistische straatnamen en standbeelden, konden overleven tot diep in het eerste decennium van de huidige eeuw. ${ }^{14}$ Eventueel nog af te handelen kwesties werden op die wijze gedurende het democratiseringsproces en de periode dat de PSOE aan de macht was (1982-1996) als het ware terzijde geschoven..$^{15} \mathrm{Er}$ mocht dan in die jaren veel gepubliceerd zijn over de burgeroorlog, de gevoelige kwesties werden zorgvuldig vermeden en onderzoek naar de periode 1936-1939 bracht weinig nieuwe informatie aan het licht, zodat veel bij het oude bleef. ${ }^{16}$

\section{De bewustwording van een verborgen verleden}

Het duurde tot midden jaren 1990 voordat het beeld van een collectief schuldgevoe zijn beste tijd gehad had. Toen tijdens de verkiezingsstrijd in 1996 twee campagnevideo's gelanceerd werden door de Catalaanse tak van de PSOE, was dat een rechtstreekse schending van de ongeschreven regel om de herinnering aan de burgeroorlog niet als politiek wapen in te zetten. De cineast Manuel Huerga liet in de video's doorschemeren dat rechts Spanje verantwoordelijk was geweest voor 
het dictatoriale verleden en dat een stem op de conservatieve Partido Popular (PP) wel eens negatieve consequenties kon hebben voor de toekomst van de Spaanse democratie. ${ }^{17}$ De waarschuwing van links bleek echter niet voldoende om de kiezer op andere gedachten te brengen, sterker nog, rechts moest er hartelijk om lachen ${ }^{18}$ en op 3 maart won de PP de verkiezingen, waardoor José María Aznar als de nieuwe premier van Spanje beëdigd kon worden.

Behalve deze twee video's die Spanjes gewelddadige en repressieve verleden in herinnering brachten, had de PSOE-regering in de herfst van 1995 een wetsvoorstel goedgekeurd waarin werd gesteld dat de nog overgebleven leden van de Internationale Brigade in 1996 - het zestigste gedenkjaar van het begin van de burgeroor$\log$ - de Spaanse nationaliteit konden aanvragen. De hoogbejaarde brigadisten zouden in het najaar van 1996 naar Spanje komen en officieel door het parlement en de premier ontvangen worden, waarna hun de Spaanse nationaliteit zou worden overhandigd. Maar op het moment suprême gaven de hoogwaardigheidsbekleders van de PP niet thuis. Zo was de kersverse premier José María Aznar de huldiging vergeten en had hij reeds andere plannen gemaakt. De voorzitter van het parlement had het te druk om een gaatje vrij te maken in zijn agenda en de burgemeester van Madrid was nergens te bekennen..$^{19}$ In heel Spanje waren er kleine pesterijen. Zo wilde de burgemeester van Albacete de brigadisten niet op het treinstation onthalen, waarop de oppositie snel een hele fanfare optrommelde zodat ze alsnog waardig ontvangen konden worden. Een PP-gemeenteraadslid verkondigde dat de brigadisten toentertijd naar Spanje waren gekomen om Spanjaarden af te slachten. Aan de linkerzijde werden de brigadisten daarentegen als helden verwelkomd. De dag na de afgang in het parlement werden ze hoffelijk ontvangen op het hoofdkantoor van de PSOE, waar Felipe Gonzalez, de voormalige premier van Spanje, hen trakteerde op een welkomstspeech. ${ }^{20}$ De komst van de brigadisten kan gezien worden als een provocatie van links om de rechtse trauma's van de burgeroorlog in herinnering te roepen, maar ook als een blootlegging van de verschillende emoties binnen de democratie die na zestig jaar nog steeds de gemoederen hoog lieten oplopen.

Naast de komst van de brigadisten, waardoor de herinnering aan Spanjes zwartste bladzijde uit de geschiedenis opeens kwam bovendrijven, kwamen er gaandeweg, door het werk van een jonge generatie historici, nieuwe en overtuigende feiten aan het licht die betrekking hadden op de slachtoffers van de burgeroorlog en het franquistische geweld. Hoewel deze onderzoeken beperkt bleven tot de academische kringen (universitaire congressen, vakbladen) en in het midden van de jaren 1990 zelden de interesse wekten van de media, druppelden de resultaten desondanks door bij het grote publiek. Er bleek sprake te zijn van een verleden dat het franquisme al die jaren angstvallig verborgen had gehouden. Het waren vooral de kleinkinderen, los nietos, van de tienduizenden slachtoffers van het Francoregime, die geïnteresseerd bleken in de resultaten. Zij vroegen zich af wat er precies gebeurd was met hun familieleden, waarom dit verleden zolang verborgen was gebleven en, in de gevallen waar sprake was van vermisten, waar hun geliefden begraven lagen..$^{21}$ Ook de oprichting van waarheidscommissies in diverse landen zoals Zuid-Afrika, Argentinië en Chili, speelde een rol in de bewustwording van Spanjes verborgen verleden. In het licht hiervan leek 'Spain's transition to democracy [...] strangely unfinished. ${ }^{22}$

In 1999 publiceerde Santos Juliá Víctimas de la guerra civil, een werk over de onderdrukking tijdens de burgeroorlog. Samen met specialisten als Julián Casanova Josep María Solé i Sabaté, Juan Villarroya en Francisco Moreno, beschreef Juliá in detail waar en hoeveel mensen tijdens de burgeroorlog gefusilleerd werden. Het uiteindelijke cijfer kwam neer op 94.699 slachtoffers aan republikeinse zijde door de franquistische repressie, en 37.843 slachtoffers aan franquistische kant door de republikeinse onderdrukking. Deze cijfers waren verre van compleet, aangezien het hier een onderzoek betrof van 25 provincies, de helft van het totale aantal provincies in Spanje. ${ }^{23}$ Daarbovenop kwamen nog eens tien provincies die gedeeltelijk onderzocht waren. Het betrof hier een aantal van 21.816 mensen die door de nacionales vermoord waren. Het 'traditionele' cijfer, en daarbij doelen de auteurs op de studie van generaal Ramón Salas Larrazábal uit 1977, Pérdidas de la Guerra, lag in bovengenoemde 25 provincies op 34.397. Anderzijds bleek dat het cijfer dat Salas aandroeg met betrekking tot de slachtoffers van de republikeinse repressie, stevig naar onderen moest worden bijgesteld: Salas kwam tot 60.628 slachtoffers in 19 provincies, de onderzoekers van Víctimas de la Guerra Civil kwamen, na 25 provincies onderzoch te hebben, op 37.843 slachtoffers. ${ }^{24}$ Een verschil dat stof tot nadenken gaf. Het was dan ook geen wonder dat Víctimas bekendheid kreeg buiten de academische wereld. Van een gelijkspel bleek geen sprake te zijn: de franquistische repressie had bijna drie keer zoveel slachtoffers gemaakt als voorheen werd aangenomen en daarbij was de helft van het land nog niet eens onderzocht. ${ }^{25}$

Indirect betekenden deze onderzoeken een publieke erkenning van de republikeinse herinnering die tijdens de dictatuur en de overgang naar de democratie onderdrukt was of als taboeonderwerp werd afgedaan. ${ }^{26}$ Juist deze groep van de Spaanse bevolking had tot dan toe geen stem binnen de samenleving, aangezien hun herinnering aan de burgeroorlog volledig verbannen was naar de privésfeer. Stap voor stap werden de visies van het Francoregime op de burgeroorlog in academische kring ontrafeld ${ }^{27}$ en vanaf het einde van de jaren 1990 'there has been an avalanche of publications - journalistic and academic -documenting the Franco regime's use of prison camps and slave labour, ${ }^{28}$ 

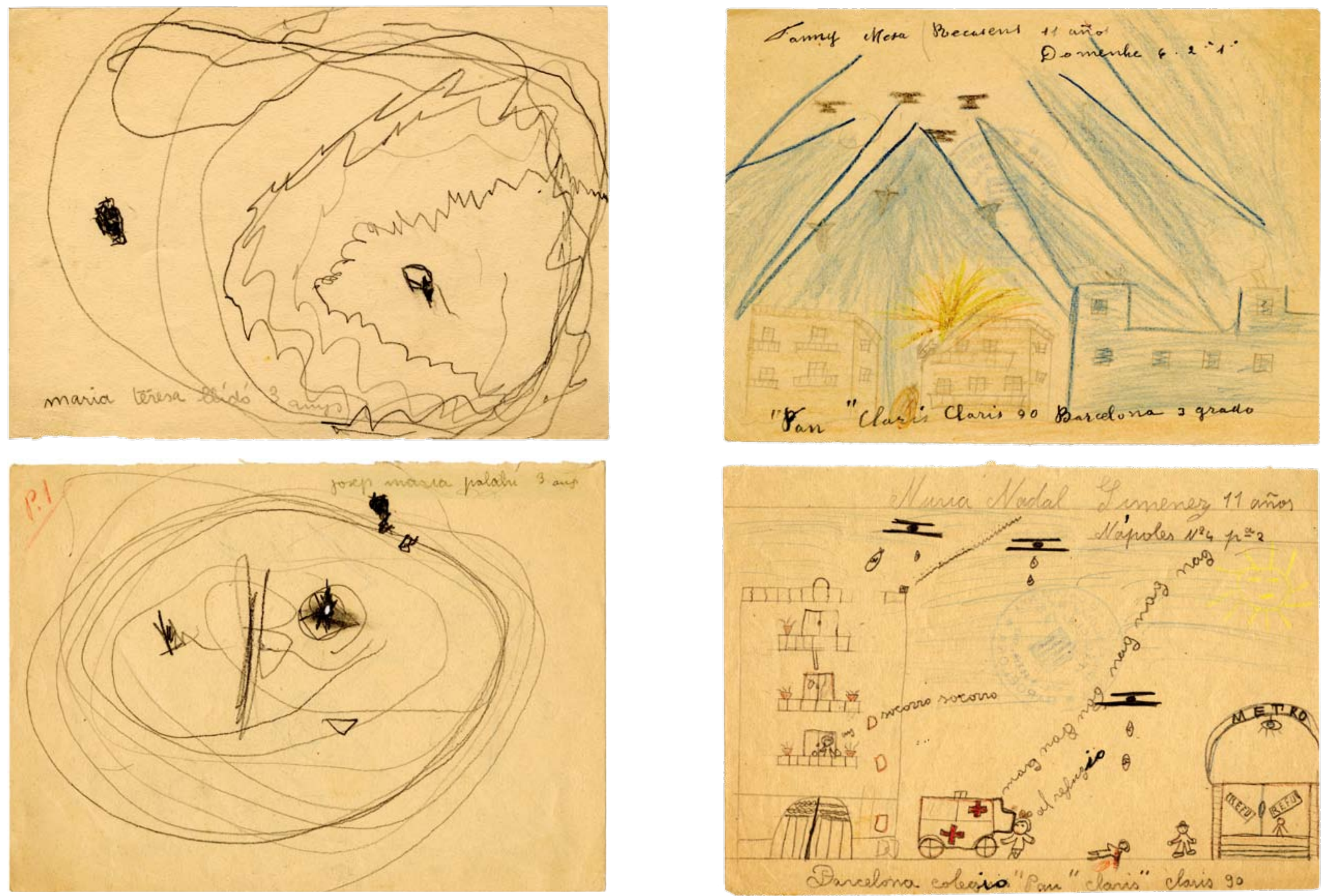
Sa maroca del pare.

27 deseorare

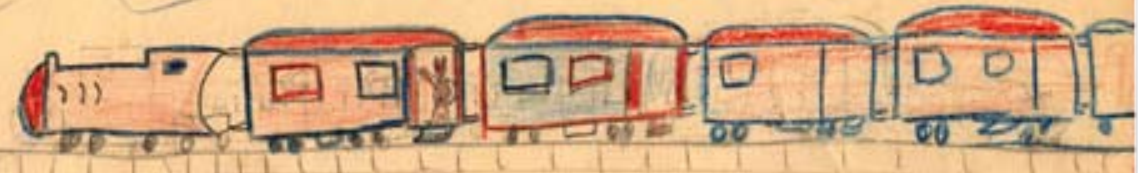

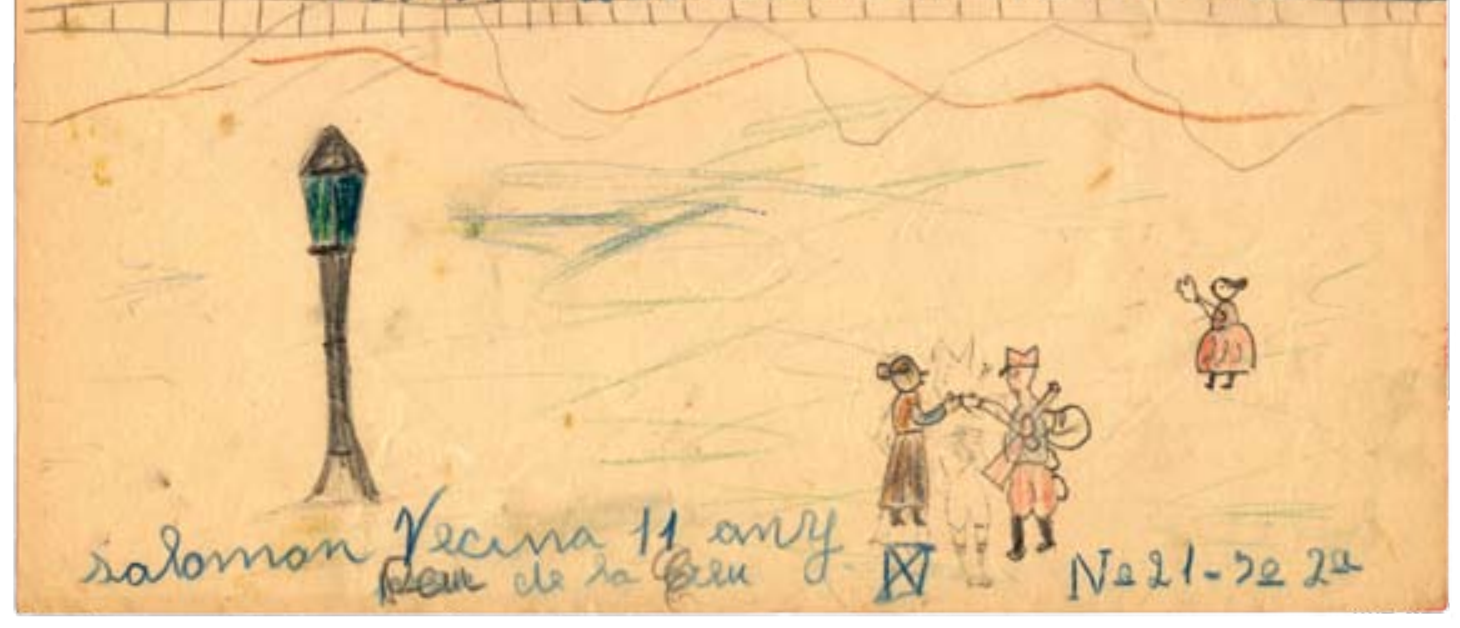

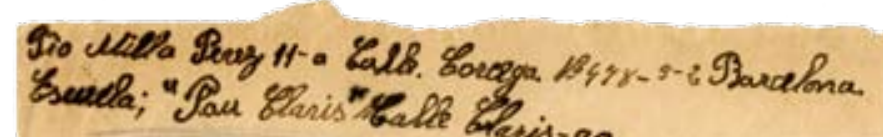

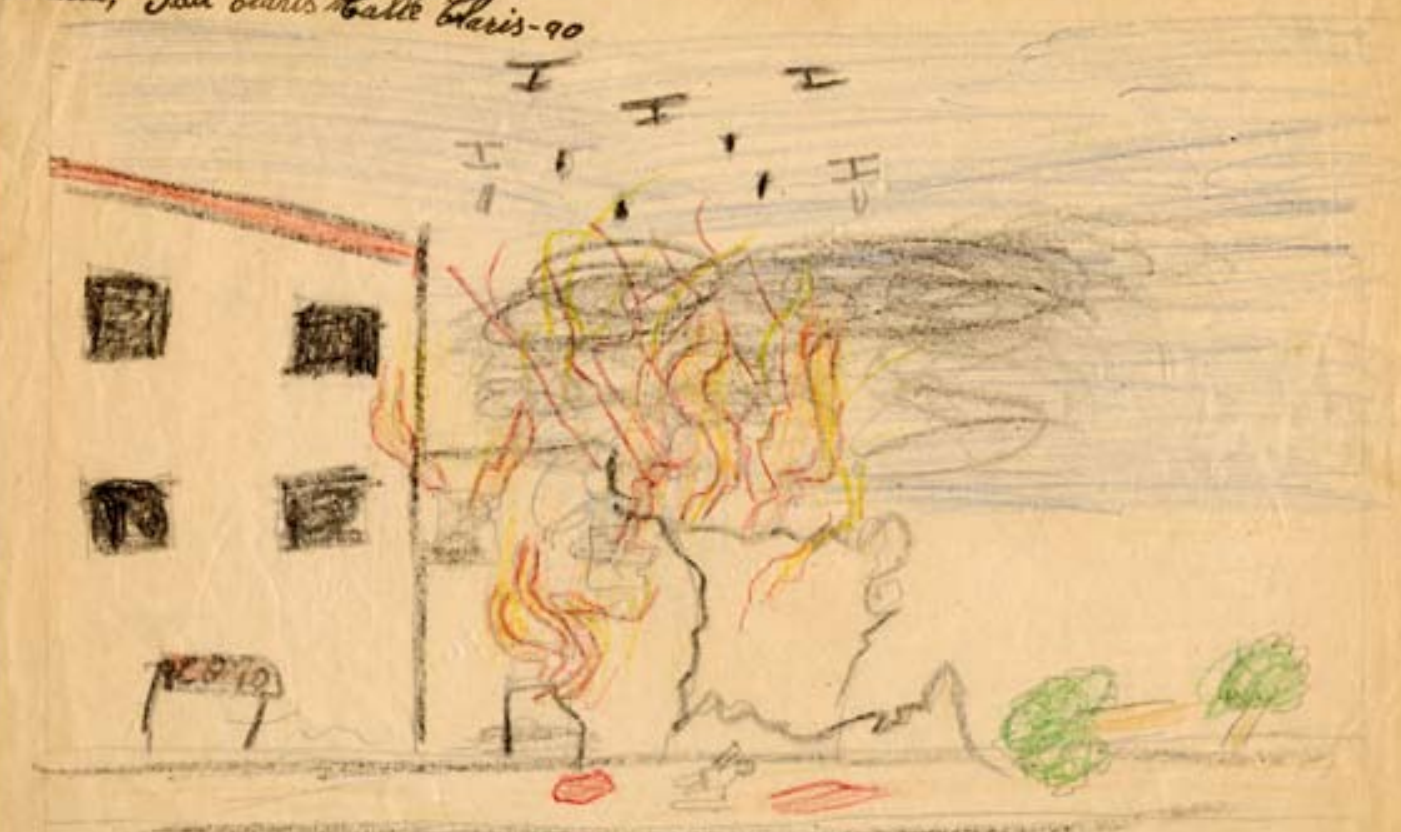

Mand Estelan Elema - Harim-Galle Brenarista 26- Rum ipal 25. Escucla "Pau Claris"- Calle Claris-90-Bancelona

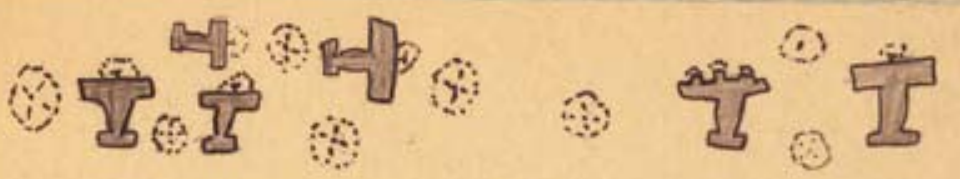

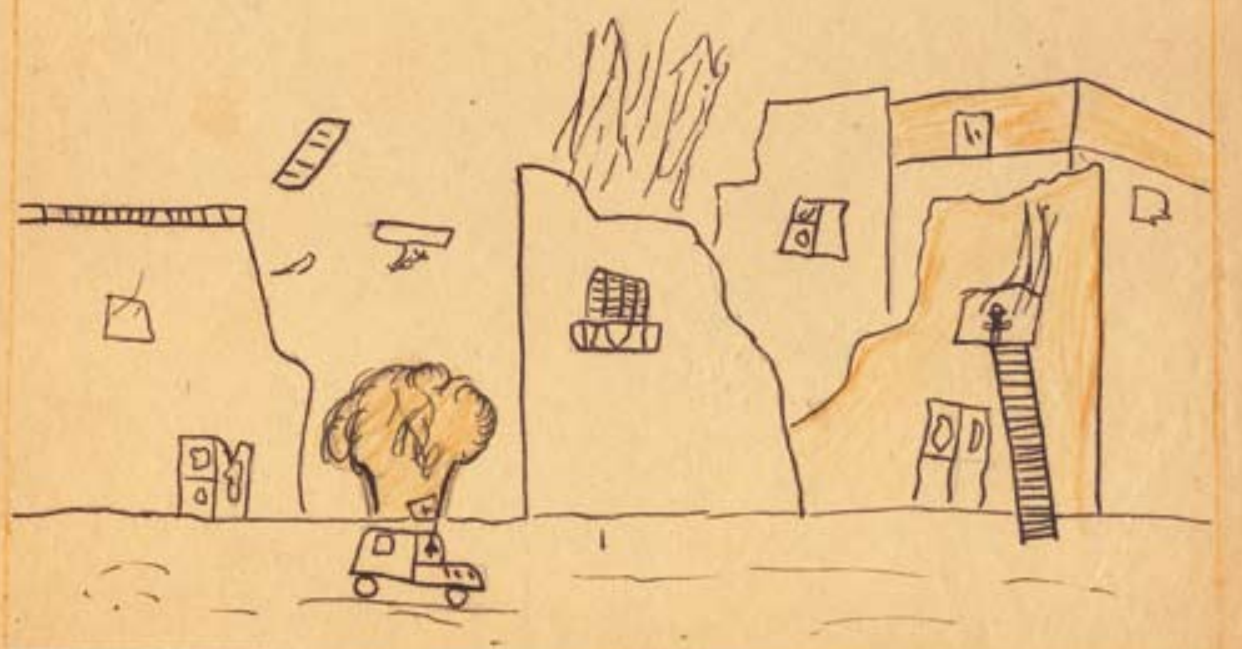

\$

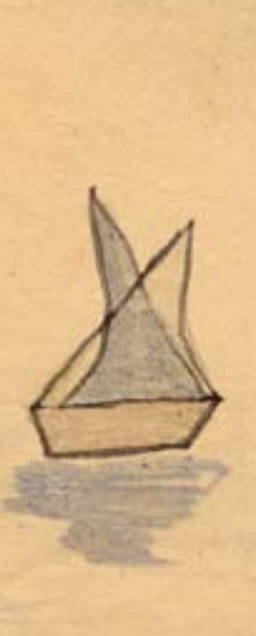

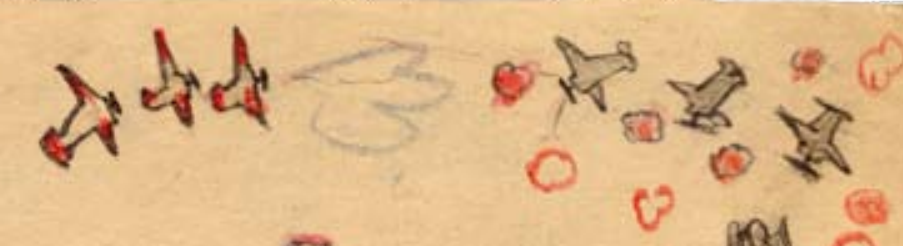

frupoescoliar pan Claris 
De reactie van conservatief rechts

Parallel aan de nieuwe geluiden rondom de franquistische repressie die gebaseerd waren op intensief en nauwkeurig onderzoek en die steeds vaker hun weg vonden naar het grote publiek, probeerde een andere sector binnen de Spaanse samenleving de afbrokkeling van de officiële kijk op de burgeroorlog tegen te gaan. Het was de toen nog onbekende Pío Moa die in de conservatieve krant $A B C$ het werk van Juliá en de vier andere specialisten als 'tendentieus en sectarisch' betitelde. ${ }^{29}$ Dit was het begin van een journalistiek discours dat betrekking had op de Tweede Republiek, het ontstaan van de burgeroorlog en de geschiedenis van Spanje in de 20e eeuw, van journalisten en historici met weinig of geen academische verdiensten (Federico Jiménez Losantos, César Vidal, José María Marco, Pío Moa). Gesteund door de conservatieve media zoals onder meer de dagbladen La Razón, ABC, El Mundo, de nieuwssite Libertad digital en COPE, het radiostation van de Spaanse bisschoppen, was dit discours, afgaande op de honderdduizenden verkochte boeken, uiterst succesvol. Hier was sprake van een neoconservatieve ideologie die verpakt werd als 'liberaal' en in grote lijnen overeenkwam met de visie op het verleden van het Francoregime. ${ }^{30}$ Pío Moa, vroeger lid van GRAPO, een linkse terroristische groepering, maakte na het democratiseringsproces een conservatieve draai en publiceer nu over de Tweede Republiek, de burgeroorlog en het Francoregime vanuit een neoconservatief standpunt. Zijn werk wordt sterk bekritiseerd door de academische wereld en over het algemeen afgedaan als politieke propaganda. ${ }^{31}$ Wetenschappers vonden het echter in eerste instantie niet nodig deze in hun ogen neofranquistische propaganda ${ }^{32}$ openlijk te bestrijden. Men wist reeds in de jaren 1960 door het werk van Herbert R. Southworth dat 'de franquistische historici nooit op serieuze wijze de problemen bestudeerd hebben die de geschiedenis van de burgeroorlog met zich meebracht': ${ }^{33}$ Maar dat een dergelijk geluid honderdduizenden mensen wist te bereiken, toont aan dat er een andere opinie leefde binnen de Spaanse samenleving. Die mocht eenvoudigweg niet genegeerd worden door historici die zich al jaren bezighielden met de bestudering van de traumatische herinnering aan de burgeroorlog. ${ }^{34}$ Een reactie kwam er in de vorm van een vijfhonderd pagina's tellend boek, Anti-Moa (2006), van historicus Antonio Reig Tapia. In het voorwoord haalt de Britse hispanist Paul Preston naast Pío Moa onder meer de schrijver César Vidal aan. Deze auteur beschikt over drie doctorsgraden (theologie, filosofie en geschiedenis) en studeerde rechten, maar waar zijn dissertaties precies te raadplegen zijn, blijft een raadsel. ${ }^{35}$ Net als Moa, is ook Vidal een werkelijk publicatiewonder: hij heeft het gepresteerd gedurende zijn loopbaan vanaf 1987 maar liefst 124 boeken te publiceren met als hoogtepunt de periode tussen 2004 en 2005 waarin 27 boeken van zijn hand verschenen. ${ }^{36}$ Dat sommige essentiële details door deze vluchtige werkwijze hier en daar dan wel eens verdraaid of ronduit verzonnen worden, nemen Vidal en co. op de koop toe. ${ }^{37}$ Desondanks moet worden gezegd dat door gebruik te maken van deze techniek en door de steun van de reeds genoemde media, deze neoconservatieve schrijvers in staat zijn gebleken een groot publiek te bereiken, waarschijnlijk veel groter dan menig 'professioneel' historicus ooit hoopt te bereiken. De hoeveelheid publicaties van deze relatief kleine groep schrijvers, uitgegeven in korte tijd, heeft in ieder geval in de Spaanse samenleving voor voldoende ruchtbaarheid gezorgd om de beweging van de historische herinnering van weerwoord te voorzien.

\section{Emilio Silva en de oprichting van de Asociación}

de la Recuperación de la Memoria Histórica

Naast de wetenschappers die zich bezighielden met het verborgen verleden van het franquisme en de reacties die deze onderzoeken opwierpen, kwamen er vanaf het jaar 2000 ook steeds vaker burgerinitiatieven van de grond. Op 28 oktober 2000 werden er in Priaranza del Bierzo, in de provincie León, dertien lichamen opgegraven die in de morgen van 16 oktober 1936 door falangisten gefusilleerd waren. Onder de slachtoffers van dit franquistische geweld bevond zich de grootvader van Emilio Silva, de initiatiefnemer van het openen van dit massagraf. Hoewel er direct na de dood van Franco ook massagraven uit de burgeroorlog waren geopend ${ }^{38}$, was het Emilio Silva's initiatief dat een sneeuwbaleffect teweegbracht. Doordat er bij de opgraving onder andere een forensisch team betrokken was, werd het mogelijk de lichamen te identificeren aan de hand van een DNA-test. De families van de overledenen konden, ruim 64 jaar na dato, eindelijk hun dierbaren op een eervolle wijze begraven. ${ }^{39}$ Op 8 oktober 2000 schreef Emilio Silva over deze op handen zijnde opgraving in La Crónica de León het artikel Mi abuelo también fue un desaparecido (Mijn grootvader was ook vermist). Hierin zinspeelde hij onder meer op het feit da de dertien van Priaranza maar het topje van de ijsberg waren, want: 'Mijn geschiedenis is een klein deel van een grote geschiedenis. Er zijn veel massagraven vo naamloze mannen. [...] Er zijn veel mensen die het niet verdragen om terug te denken maar dat wil niet zeggen dat ze het niet meer weten. Daarom is ruchtbaarheid noodzakelijk, opdat de herinnering opnieuw ontwaakt en de droom verlaat die haar gedurende zo veel jaren in slaap heeft gehouden."40

Ruim een maand later, dus na de opgraving, vertelde Silva in een ingezonden brief aan de krant El País nogmaals over Priaranza del Bierzo. ${ }^{41}$ Het enige wat nu nog restte, zo schreef hij, was de identificatie van de lichamen, zodat zijn familie voor een eervolle begrafenis van zijn grootvader kon zorgen. Emilio Silva schreef dit in de maand dat het 25 jaar geleden was dat Franco stierf en merkte op dat er nog steeds duizenden Spanjaarden waren die vergeten en verlaten hun laatste rustplaats hadden in greppels en heuvels. Dat de dertien van Priananza geen geisoleerd geval waren en dat Silva's initiatief niet onopgemerkt bleef, bleek uit een ingezonden brief in de krant El País twee dagen na Franco's 25e sterfdag. Terwij Silva's brief de titel No muere la memoria droeg, had deze brief als titel La memoria no muere en was een antwoord op Silva's oproep om vooral niet te vergeten. De briefschrijfster reikte Silva de hand: laten we de angst van ons afgooien en met elkaar gaan praten, was haar boodschap. ${ }^{42}$ 


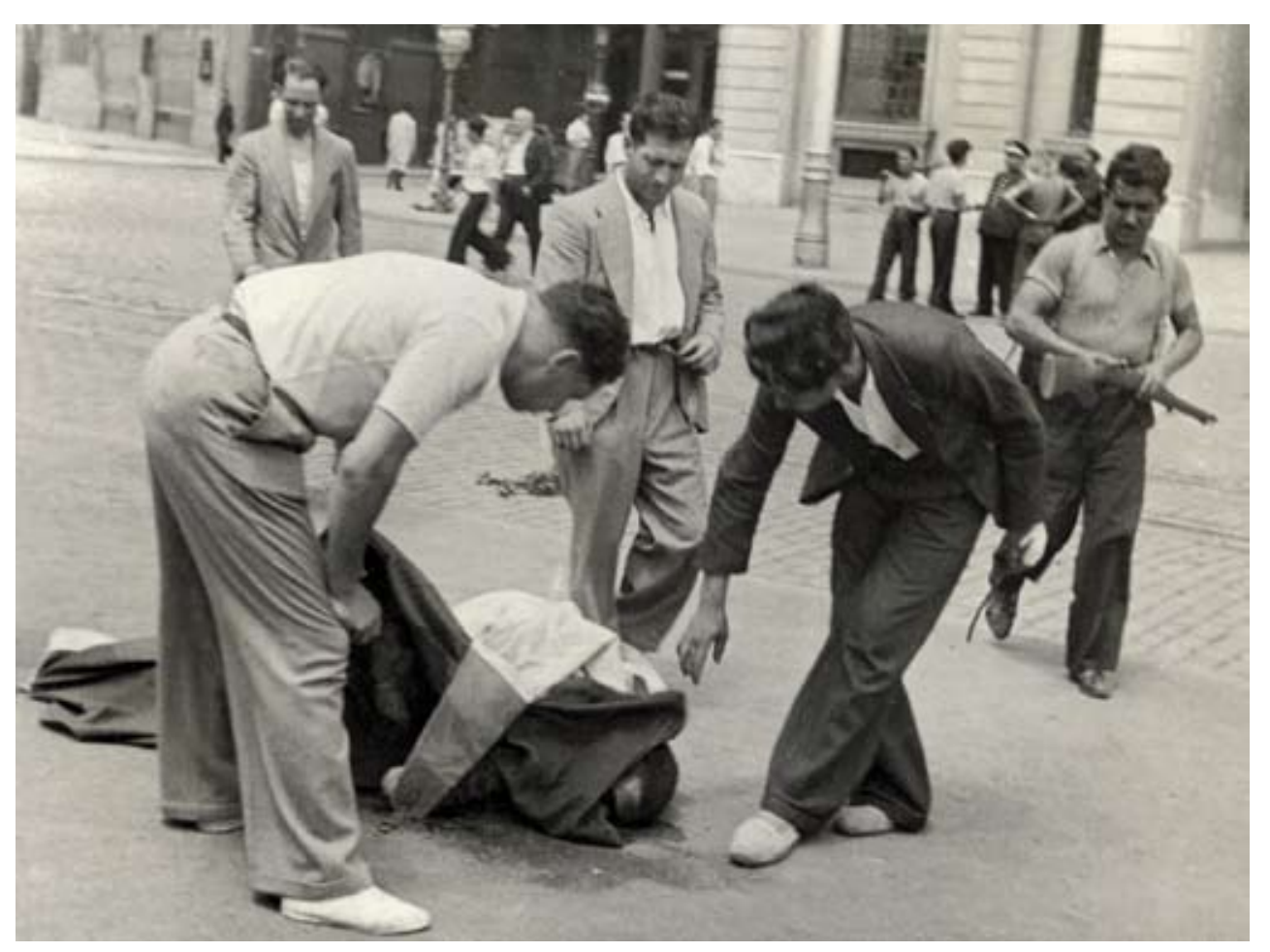

Militieleden inspecteren een lijk, vermoedelijk in de straten van Barcelona. (Amsab-ISG, Gent)

Samen met Santiago Macías ging Silva tot actie over. Eind 2000 richtten zij de Asociación para la Recuperación de la Memoria Histórica (ARMH) op ${ }^{43}$, een vereniging met als doelstelling het lokaliseren en opgraven van massagraven uit de burgeroorlog, om de hierin aangetroffen lijken te identificeren. ${ }^{44}$ Met de oprichting van de ARMH begon men in 2001 letterlijk met het graven in het verleden om de waarheid boven water te krijgen. Hoewel de ARMH een initiatief was van een nieto, waren het niet enkel de kleinkinderen die de beweging voor herstel van de herinnering droegen. $\mathrm{Nu}$ in Spanje een cultureel en maatschappelijk draagvlak rondom de traumatische herinnering vorm kreeg, zagen de republikeinse grootouders hun kans schoon om hun verhaal van de burgeroorlog over te dragen aan de jongere generaties ${ }^{45}$ Het was dus de oude generatie die de ARMH in eerste instantie voorzag van de noodzakelijke details om een opgraving mogelijk te maken.

Mede daardoor kon de ARMH zich als een olievlek over heel Spanje verspreiden, met allerlei regionale vertakkingen. ${ }^{46} \mathrm{Er}$ wordt geschat dat er over heel Spanje nog zo'n 30.000 slachtoffers van de franquistische repressie in massagraven liggen. Van dit aantal waren er tot 2005 door de ARMH ten minste 683 opgegraven. ${ }^{47}$

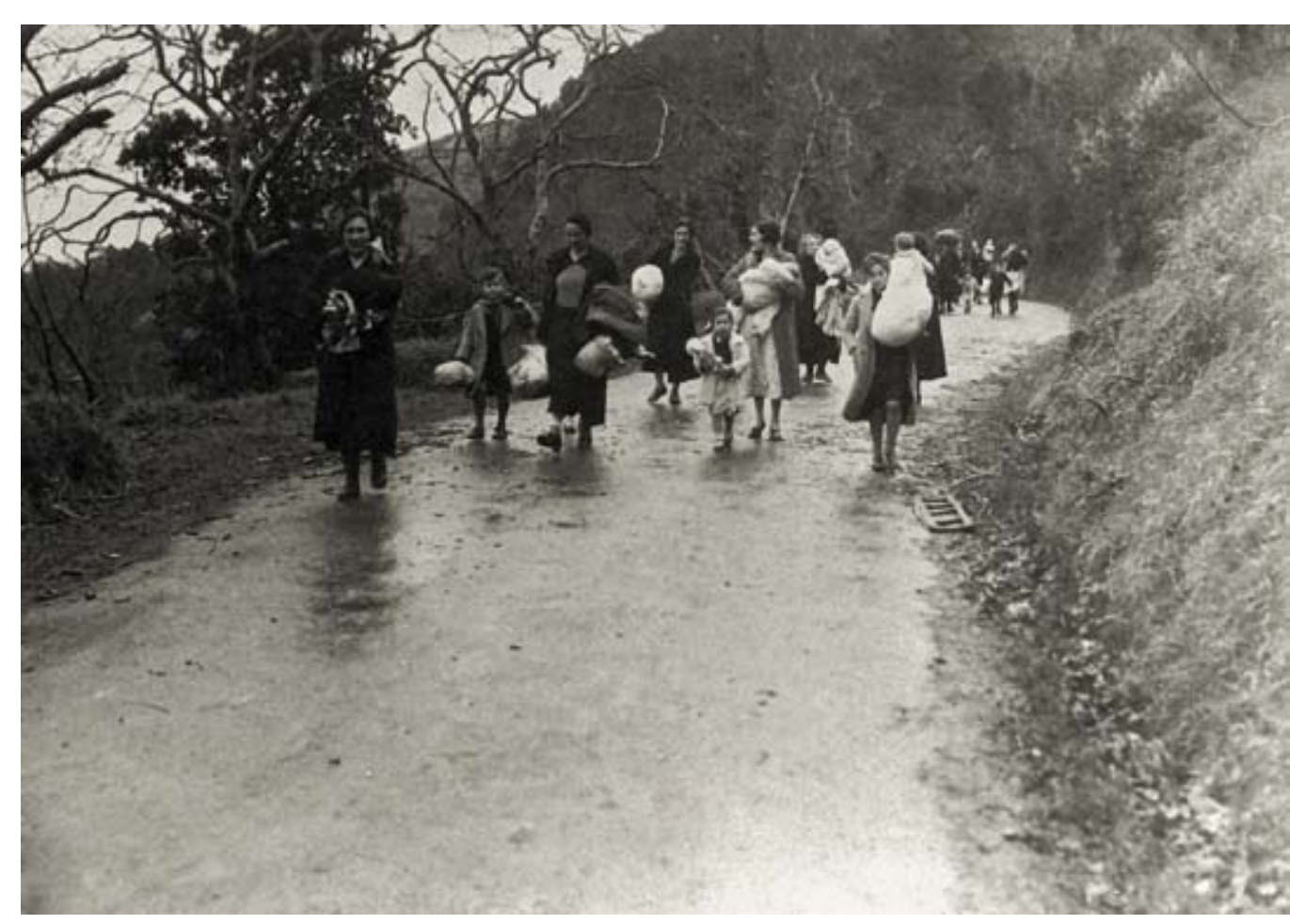

Vrouwen en kinderen op de vlucht tijdens de burgeroorlog (Amsab-ISG, Gent)

\section{Maatschappelijk debat}

Tegelijk met de verspreiding van deze vereniging over heel Spanje ontspon zich in de daaropvolgende jaren eindelijk een maatschappelijk debat rondom de omgang met het verborgen verleden. Binnen dit debat zijn er tal van onderwerpen, residu's van een onverwerkt verleden, die na de bijna veertigjarige dictatuur plus de beginjaren van de democratie hun plaats opeisen binnen de Spaanse samenleving. De republikeinse herinnering die zich jarenlang in familiekring had verscholen, trad, zij het in eerste instantie voorzichtig, naar buiten; de franquistische dreiging was voorbij. Met de ARMH als ijsbreker en historisch onderzoek als fundament werden er tal van initiatieven op het getouw gezet om de republikeinse herinnering in de openbaarheid te brengen en bespreekbaar te maken. ${ }^{48}$ Toen in maart 2004 de PSOE onverwachts de verkiezingen won, werd er een herinneringsbeleid ontwikkeld waardoor een aantal zaken in een stroomversnelling kwamen. De ARMH vond een luisterend oor bij de socialistische regering. Hun eis om voor eens en altijd de franquistische symbolen uit het openbare leven te verwijderen, werd drie jaar later ingewilligd met de wet op de Historische Herinnering (Ley de la Memoria Histórica). ${ }^{49}$ Verder liep de teruggave van het archief van Salamanca aan Catalonië, een kwestie die al speelde vanaf het begin van de overgang naar de democratie, uit op stevige 


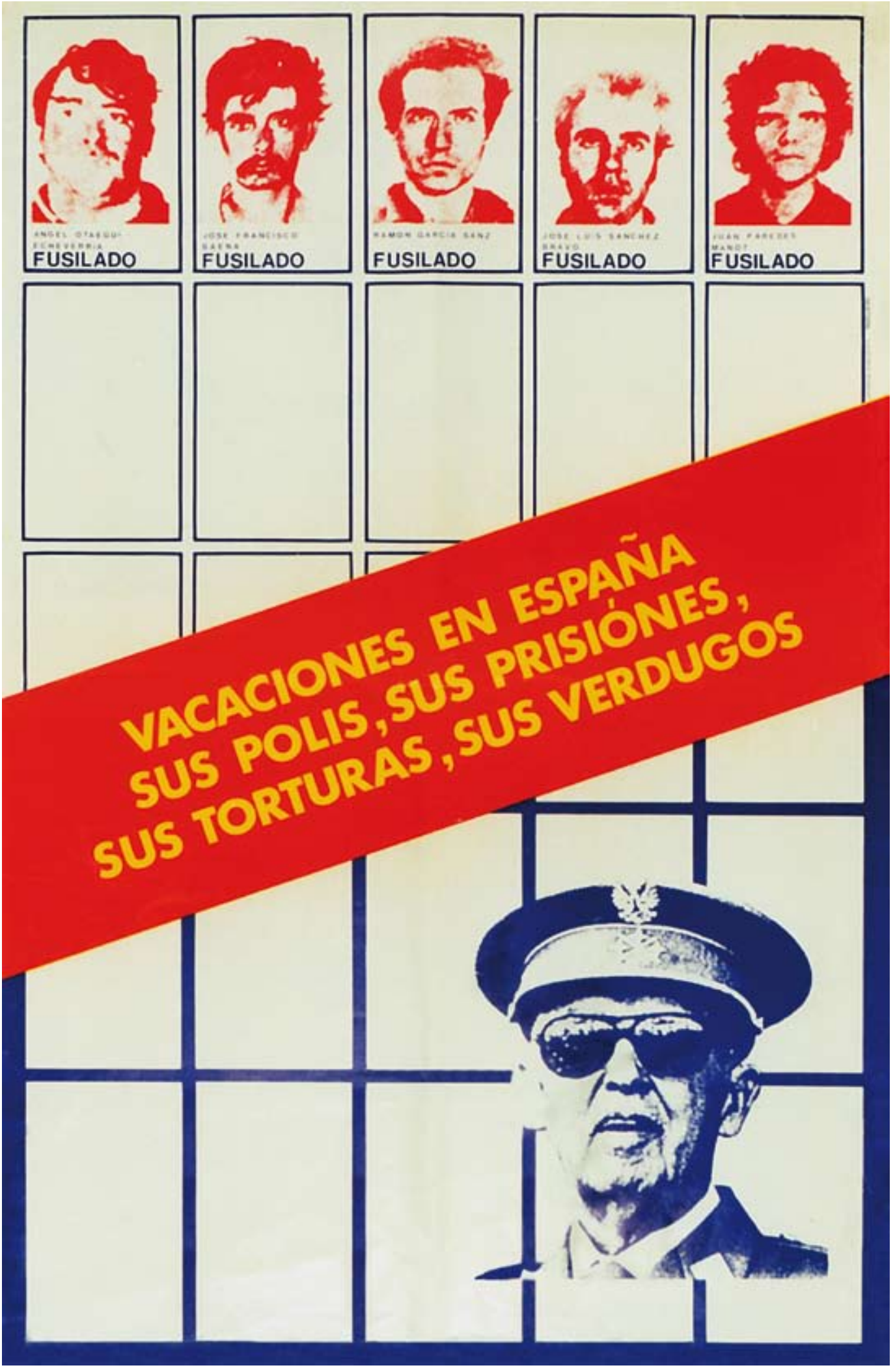

demonstraties, maar uiteindelijk werd die in 2005 afgerond. Dit archief werd in juli 1939 in beslag genomen door Franco, per trein van Barcelona naar Salamanca vervoerd, en gebruikt om aanhangers van de republiek op te sporen en te vervolgen. Tegenstanders van een teruggave wilden dat het archief een geheel bleef en vreesden ook voor de eenheid van het land, mocht de teruggave doorgang vinden..$^{50}$

Een ander element binnen het herinneringsdebat was de zogenaamde oorlog van de overlijdensberichten, la guerra de las esquelas. Op 17 juli 2006 liet de dochter van Virgilio Letret Ruiz voor bijna 7500 euro een advertentie plaatsen in El País om haar vader te herdenken die eenenzeventig jaar eerder in Melilla was geëxecuteerd door de militairen die vanuit Afrika in opstand kwamen tegen de republiek. Dit leidde tot een stroom van overlijdensberichten gerelateerd aan de burgeroorlog in de dagbladen El País, El Mundo en $A B C$, waarbij de laatste twee het conservatieve gedachtegoed vertegenwoordigden. ${ }^{51}$

Hoe men ook tegen de omgang van het verleden in Spanje aankijkt, de doorbraak van de republikeinse herinnering heeft een fel debat teweeggebracht in de Spaanse samenleving. Ondanks de tomeloze onderzoeksdrift van historici en de inzet van vele particuliere initiatieven die keer op keer het franquisme in zijn wreedste vorm blootleggen, blijft een groot gedeelte van de Spaanse bevolking vasthouden aan opvattingen die hun oorsprong vinden in de overgang van dictatuur naar democratie. ${ }^{52} \mathrm{Dit}$ is bij nader inzien ook niet zo vreemd. Rechts Spanje had reeds tijdens de dictatuur het leed van het verlies van hun dierbaren ruimschoots kunnen verwerken. De dictatuur had hun slachtoffers uit de massagraven gehaald, had ze een eervolle begrafenis gegeven en herdacht. Met de invoering van de democratie en goedkeuring van de amnestiewet in 1977, ging en gaat men ervan uit dat de burgeroorlog definitief tot het verleden behoort. Een oprakeling van het trauma is dan ook nergens voor nodig en zou alleen maar kunnen leiden tot het openen van oude wonden. In plaats van een van de donkerste periodes uit de Spaanse geschiedenis te herinneren zou men juist een van Spanjes finest moments moeten aanhalen, namelijk het democratiseringsproces en de hieruit ontstane verzoening tussen de twee Spanjes. ${ }^{53}$

Terwijl rechts liever geen maatschappelijke discussie ziet over de burgeroorlog, bestaat er binnen de zogenaamde beweging La Recuperación de la Memoria Histórica (Herstel van de Historische Herinnering) geen consensus over welke plaats de republikeinse herinnering binnen de samenleving moet innemen. Grofweg kunnen er drie standpunten onderscheiden worden. ${ }^{54}$

Allereerst bestaat er een visie die grotendeels overeenkomt met het beleid van de PSOE, waarbij de erkenning van de republikeinse slachtoffers van de burgeroorlog een aantal juridische, politieke, economische en culturele grenzen niet mag overschrijden. Deze politieke visie wordt ondersteund door een groep intellectue- 
len die het zogenaamde 'herstel' van de herinnering binnen de aangegeven grenzen probeert te houden. Men houdt vast aan de opvatting dat er al vanaf het democratiseringproces een enorme hoeveelheid gepubliceerd is over de burgeroorlog en dictatuur en dat er van 'vergeten' geen sprake kan zijn. ${ }^{55}$ Hieraan is de opvatting van rechts en gematigd links gekoppeld, dat de officiële verzoening, amnestie en het collectief verantwoordelijkheids- en schuldgevoel ten tijde van het democratiseringsproces heilige waarden zijn en als basis gelden van de Spaanse democratie, waaraan niet getornd mag worden.

Ten tweede worden de aangegeven grenzen van het herinneringsbeleid door een ander deel van deze beweging - door historicus Julio Aróstegui maximalista genoemd - juist verworpen. Hierbij draait het om het omvormen van de kijk op het verleden en volgens deze opvatting moet de herinneringspolitiek veel dieper gaan. Zo zouden bijvoorbeeld de franquistische vonnissen nietig verklaard moeten worden door de huidige rechterlijke macht (juridisch) en moet de politiek zich duidelijk uitspreken over de onwettigheden van het franquistische regime (politiek), zodat eventuele claims van de slachtoffers van het franquisme gehonoreerd kunnen worden (economisch).

Ten derde is er nog een radicale sector die het gehele democratiseringsproces in twijfel trekt en hierin bevindt zich de kern van de beweging. Volgens deze sector moet op cultureel gebied het verzoenende imago van het democratiseringsproces juist ontmanteld worden. Of het daar ooit van komt zal de toekomst moeten uitwijzen. Zolang rechts geen water bij de wijn doet en links de door de politiek als veilig bestempelde paden blijft bewandelen, is er volgens Espinosa sprake van een obstrucción del pasado ${ }^{56}$, oftewel een verleden waarover geen consensus bestaat waardoor onder meer een nationale herdenkingsdag nog altijd op zich laat wachten.

\section{Baltasar Garzón}

De vraag is hoe Spanje deze impasse over het verleden kan doorbreken. Op 16 oktober 2008 gaf de Spaanse onderzoeksrechter Baltasar Garzón ${ }^{57}$ in een juridisch document, opgesteld in samenwerking met de ARMH, te kennen een onderzoek te willen starten naar de verdwijning van 114.266 personen tussen juli 1936 en december $1951 .{ }^{58}$ In dit document worden Franco en 34 andere leiders van de militaire opstand uit 1936 ervan beschuldigd misdaden tegen de menselijkheid te hebben begaan door hun tegenstanders op systematische wijze te elimineren. Maar al gauw was er kritiek te horen op de werkwijze van Garzón. De openbare aanklager van het Spaanse Hooggerechtshof, Javier Zaragoza, verklaarde dat Garzón nie competent zou zijn om een dergelijk onderzoek uit te voeren. Franco en de 34 andere verantwoordelijken beschikten namelijk over bepaalde privileges, waardoor het onderzoek niet door een rechter van de Audiencia Nacional ${ }^{59}$ zoals Garzón uitgevoerd kon worden, maar het onderzoek thuishoorde bij het Tribunal Supremo (Hoge Raad). Ook zou dit onderzoek een schending betekenen van de overeengeko-

men amnestiewet uit $1977 .{ }^{60}$ Dit leidde er uiteindelijk toe dat Garzón zich terugtrok maar niet alvorens een beroep gedaan te hebben op de regionale rechtbanken om desondanks het onderzoek voort te zetten.

In januari van 2009 deed de ultrarechtse beweging Manos Limpias (Schone Handen) er nog een schep bovenop door een aanklacht in te dienen tegen Garzón omdat die een onderzoek begon dat niet onder zijn bevoegdheid viel. Deze aanklach werd uiteindelijk in mei van datzelfde jaar in behandeling genomen door de Hoge Raad en hoewel een uitspraak bij het schrijven van dit artikel nog niet bekend is, trekt het proces tegen de bekendste Spaanse onderzoeksrechter, en daarmee ook de gepleegde misdaden tijdens de burgeroorlog en het dictatoriale regime, ook internationaal de aandacht. Zo liet de Internationale Commissie van Juristen (ICJ) in een persbericht weten bezorgd te zijn over 'the criminal prosecution of Spanish Examining Magistrate Baltasar Garzón Real for his investigation into crimes agains humanity committed during and after the Spanish Civil War (1936-1939)'. En verder riep de ICJ in herinnering dat onder internationaal recht: 'Legislation punishing crimes against humanity may be applied retroactively (Article 15(2) ICCPR and Article 7(2) ECHR), that no Amnesty Law (notably the Spanish Amnesty Law of 1977) can hinder their investigation and prosecution, and that statutory limitations are not applicable to such crimes. ${ }^{61}$

Of de amnestiewet van 1977 straks daadwerkelijk via het internationaal recht omzeild kan worden en daarmee de 'obstructie van het verleden' kan worden tenietgedaan waardoor men actief een onderzoek kan starten naar de 114.266 slachtoffers van het franquisme, valt af te wachten. Het feit is wel dat de doorbraak van de republikeinse herinnering in Spanje een debat teweeg heeft gebracht dat in elke laag van de bevolking gevoerd wordt. En hoewel men over de uitkomst ervan nog in het duister tast, is een dergelijke discussie, 71 jaar na het einde van de burgeroorlog, een grote overwinning voor iedereen die de Spaanse democratie een warm hart toedraagt.

1 Amnestía al fin. In: El País, 15/10/1977.

Javier PRADERA, Los escarmientos de la memoria. In: El País, 17/07/1996.

Paloma AGUILAR, Memory and Amnesia. The to Democracy, New York: Berghahn Books, 2002. Dit is de Engelse vertaling. 4 Paloma AGUILAR, Memory and Amnesia [...],
p. xviii-xxii, 265-270.

E. GONZÁLEZ DURO, La sombra del geneal. ¿Qué queda del franquismo en España?, p.110-140.
6 Santos JULIÁ, Echar al olvido. Memoria y mnistía en la transición. In: Claves de razón práctica, (2003)129, p. 14-25.

7 Santos JULIÁ (red.), Memoria de la guerra y Generales, 2006, p. 15-26.

8 Julio ARÓSTEGUI \& François GODICHEAU (red.), Guerra Civil. Mito y memoria Madrid: Marcial Pons, 2006, p.57-92.

9 Francisco ESPINOSA MAESTRE, Contra el olvido. Historia y memoria de la guerra civil, Barcelona: Crítica, 2006, p. 171-204.

10 Santos JULIÁ, Saturados de memoria. In: El País, 21/07/1996. 
11 'Wanneer men vandaag de dag zegt dat het noodzakellkk is onde "vergetelheid te van de ballingschap, van de doden, van de Oorlog, omdat de officiële geschiedenis dit verzwegen heeft, omdat dit buitengesloten werd van de herinnering, dan negeert men de publicaties over al die zaken die net na de dood van Franco verschenen en die tegenwoordig reiken tot overweldigende hoeveelheden.' (Vertaald uit het Spaans).
Uit: Santos JULIÁ, Echar al olvido [...], p. 17.

12 Santos JULIÁ, El Franquismo: Memoria y Historia. In: Claves de la razón práctica,

13 De PSOE verkreeg 48,40 procent van de stemmen terwijl de Alianza Popular, die rechtstreeks uit het franquisme stamde, a tweede overzicht van de resultaten, zie: Jesús $A$. MARTÍNEZ (red.), Historia de España. Siglo XX. 1939-1999, Madrid: Cátedra, 1999, p. 309.

14 Santos JULIÁ, El Franquismo [...], p.10.

15 Javier CERCAS, ¿Cómo acabar de una vez por todas con, el franquismo? In. El Pals,

16 Francisco ESPINOSA MAESTRE, De saturaciones y olvidos. Reflexiones en torno a un pava, (2007)7 p. 420 .

Il País, 22/02/199/

8 Jaime CAMPMANY, Los vídeos. In: $A B C$ 20/02/1996.

19 El País, 07/11/1996.

20 El País, 08/11/1996.

21 Julián CASANOVA, Mentiras convincentes. In: El Pais, 14/06/2005.

22 Sebastiaan FABER, The Price of Peace: Historical Memory in Post-Franco Spain. In:

23 Uit recent onderzoek blijkt dat het aantal slach fors van de franquistische represse L. BERNECKER, 'Luchas de la memorias' la España del siglo XX. In: Josefina CUESTA (red.), Memorias históricas de España (siglo XX), Madrid: Fundación Francisco Largo Caballero, 2008, p. 52 en voetnoot 25.

24 Santos JULİ́ (red.), Víctimas de la guerra civil, Madrid: Ediciones Temas de Hoy, 2001, p. 407-413.

25 In de academische wereld verschenen
er al vanaf de jaren 1980 studies over d franquistische repressie die lieten zien dat het 'traditionele' cijfer van het aantal Alberto REIG TAPIA, Memoria viva y memoria olvidada de la guerra civil. In: Sistema, (1997)136, p. 39.

26 Helen GRAHAM, Coming to Terms with the Past: Spain's Memory Wars. In: History Today, (2004)54, p. 29-31.

27 Julián CASANOVA, Mentiras [...].

28 Helen GRAHAM, New myths for the old. In: New York Times Literary Supplement,

29 Alberto REIG TAPIA, Dignificación Republicana y depuración franquista. In: Claves de

30 Pedro RUIZ TORRES, Los discursos de la Novo Revista de Historia Contemporánea (2007)7, p. 305-334.

31 "Het betreft een "politiek fenomeen" van een socioculturele insteek, dat zich richt op het democratie.' (Vertaald uit het Spaans). Uit: Enrique MORADIELLOS, Revisión histórica crítica y revisionismo político presentista: el caso español. In: Josefina CUESTA (red.), Memorias históricas [...], p. 375.

32 'What we get, though, is not an unraveling of myths through the complicated business
of historical analysis, but a rather crude repackaging of Francoist propaganda.' Uit: Helen GRAHAM, New myths [...]. Grahan doelt hierbij op de werkwijze van Moa bj het boek Los mitos de la guerra civil.

33 'Het is overduidelijk dat de franquistische historici nooit op serieuze wijze de problemen bestudeerd hebben die de geschieden van de Spaanse Burgeroorlog met zich Herbert R. SOUTHWORTH, El mito de la cruzada de Franco, Barcelona: Random House Mondadori, 2008, p. 514.

34 Voor een helder en beknopt overzicht van dit neofranquistisch geluid in het Nederme in de geschiedschrijving over de Spaanse burgeroorlog. Het neofranquistisch offensi van Pío Moa. In: Brood \& Rozen, (2005)3. Voor een overzicht in het Spaans, zie: Alberto REIG TAPIA, Anti Moa, Barcelona: Ediciones

35 Alberto REIG TAPIA, Anti Moa [...], p. 357, voetnoot 43.

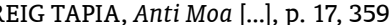
360.
37 Contra la manipulación. In: El País, Cis ook: Francisco ESPINOSA El fenómeno revisionista o los fantasmas de derecha española. En: Alberto REIG TAPIA, Revisionismo y política, Madrid: Foca, 2008

38 Francisco ESPINOSA MAESTRE, Historia, memoria, olvido: la repression franquista. In: Francisco ESPINOSA MAESTRE, Contra el olvido [...], p. 305, verwijzing 8 naar Gregor HERRERO BALSA \& Antonio HERNANDEZ

GARCIA, La represión en Soria durante la

38 Francisco ESPINOSA MAESTRE, Historia, memoria, olvido: la repression franquista. In: Francisco ESPINOSA MAESTRE, Contra el olvido [...], p. 305, verwijzing 8 naar Gregor HERRERO BALSA $\&$ Antonio HERNANDEZ Guerra Civil, Soria a ure ditie, 1982

39 El País, 19/10/2003. Silva's grootvader was het eerste slachtoffer van de Spaanse eidentificerd.

40 Maarten STEENMEIJER, Een continent in het klein. Cultuurwijzer voor het moderne Spanje.

El País, 07/11/2000.

42 El País, 27/11/2000

43 Nederlandse vertaling: Vereniging voor het Herstel van de Historische Herinnering. Website: http://www.memoriahistorica.org laatst geraadpleegd op 5 mei 2010 .

44 Emilio SILVA, Las fosas de Franco. Crónica de un desagravio, Madrid: Ediciones Temas de Hoy, 2006, p. 196.

45 R.F. BERMEJO, 'Los años difíciles' recupera la memoria de la guerra civil española. In: El País, 26/09/2002.

46 Voor een gedeeltelijk overzicht van Las Asociaciones de la Recuperación de la Memoria, zie: Walter L. BERNECKER \& Sören BRINKMANN, Kampf der Erinnerungen. Der Spanische Bürgerkrieg in Politik un Gesellschaft 1936-2006. Nettersheim: Verla Graswizlos (2008) spreett v. 369 .370. 170 groeperingen.

47 Enrique MORADIELLOS, Revisión histórica [...], p. 385 .

48 Voor een beknopt overzicht, zie: Walter L. BERNECKER \& Sören BRINKMANN, Kampf der der Vergangenheit 1996 2004, p. 292-302.
49 Officieel staat ze bekend als de wet 'die de rechten erkent en aanvult en die maatregelen invoert ten gunste van degenen die vervolging of geweld hebben ondergaan tijden de burgeroorlog en de dictatuur'. (Vertaald
uit het Spaans). Ze werd op 31 oktober 2007 goedgekeurd door het Spaanse parlement. Alleen de PP en ERC waren tegen. Zie: El País, 01/11/2007.

50 El País, 11/06/2005.

51 Maarten STEENMEIJER, Een continent in het klein [...], p. 155.

52 Julián CASANOVA, Setenta años de la victoria de Franco. In: El País, 29/03/2009.

El Mundo, 08/10/2007.

54 Julio ARÓSTEGUI, Memorias, Historias y Confrontaciones. Los conceptos y el debate. p. 35.

55 Santos JULIÁ, Echar al olvido [...]

6 Francisco ESPINOSA MAESTRE, De saturaciones [...], p. 440.

57 Garzón was ook de rechter die een internationaal arrestatiebevel liet uitvaardigen tegen Augusto Pinochet vanwege marteling en moord op Spaanse burgers tijdens zijn dictaturr. In 1998 werd Pinochet, tijdens bijna zondheidsreden werd uiteindelijk besloten Pinochet niet uit te leveren aan Spanje.

58 Het document kan je downloaden via de volgende link: http://www.elpais.com/ espana/20081016elpepunac 4 Pes PDF.doc, laatst geraadpleegd op $05 / 05 / 2010$. 59 Een speciale rechtbank die vanuit Madrid
opereert, maar over heel het grondgebied bevoegd is inzake corruptie, terrorisme en georganiseerde misdaad.

60 El País, 21/10/2008

61 Zie: http://www.icj.org/IMG/PRGarzon.pdf, laatst geraadpleegd op 05/05/2010. 